\title{
Figures and frames
}

Figures (Sections I and II) are tables and diagrams which serve to support the text, and, correspondingly, the text to explicate. Frames (Section III) are images from the films explored functioning as a visual orientation.

\section{Section I - Two Regimes of Images}

I.01 Bergson: the sensory-motor schema and pure memory 8

I.02 Bergson: correlates of the sensory-motor system and pure memory 9

I.03 Deleuze: the movement-image and time-image after Bergson 15

I.04 Pierce: first trichotomy (1868) 21

I.05 Pierce: the three trichotomies (1903) 22

I.06 Peirce: ten classes of full signs from nine sign divisions (1903) 23

I.07 Peirce: ten classes of full signs as emergent series (1903) 24

I.08 Peirce: ten classes with examples from Peirce and Tsang after Merrell 25

I.09 Peirce: ten classes showing semiotic generacy and degeneracy 25

I.10 Peirce: the ten trichotomies (1908) 26

I.11 Deleuze: the correspondence between Bergson and Peirce 29

I.12 Deleuze: image, polarity and triadic sign series 31

I.13 Deleuze: movement-image logic of domains and sign divisions 32

I.14 Deleuze: ten images, five avatars, three domains of the movement-image (with perception as zeroness) 36

I.15 Deleuze: movement-image logic of domains, avatars and images through sign combinations

I.16 Deleuze: images and signs of the movement-image in the recapitulation of Cinema 2

I.17 Deleuze: images and signs of the movement-image in the glossary of Cinéma 1 (Deleuze, 2010) 39

I.18 Deleuze: images and signs of the movement-image in the text of Cinema 1 
I.19 Deleuze: additional images and signs of the movement-image in the text of Cinema 2

I.20 Deleuze: time-image images and signs 46

I.21 Deleuze: syntheses of time 49

I.22 Deleuze: syntheses of time and time-images 54

I.23 Deleuze: syntheses of time and space 58

$\begin{array}{ll}\text { I.24 Deleuze: syntheses of space and time-images } & 60\end{array}$

I.25 Deleuze: syntheses of time, space and consciousness 63

I.26 Deleuze: syntheses of consciousness and time-images 66

I.27 Deleuze: time-images and the syntheses of time, space and $\begin{array}{ll}\text { consciousness } & 68\end{array}$

I.28 Deleuze: movement-image and time-image domains 73

\section{Section II - A Series of Images and Signs}

II.01 Solid perception: all images revolve around a central and privileged image

II.02 Liquid perception: the flow from character/event to character/event

II.03 Gaseous perception: all images resonate with one another as an acentred system

II.04 Icon: the face expressing unfilmable internal intensities 83

II.05 Dividual: the conjunction of collective and individual affects $\quad 84$

II.06 Any-space-whatever: the expression of non-human affects $\quad 85$

II.07 Symptom: characters overwhelmed by primal forces $\quad 88$

II.08 Fetish: a special object charged with primal energies, awaiting $\begin{array}{ll}\text { a grounding } & 89\end{array}$

II.09 Originary world: a universe of primal forces 90

II.10 Index of lack: the situation is an ellipsis which is unequivocally revealed 93

II.11 Index of equivocity: the situation is revealed as ambiguous 94

II.12 Vector: multiple situations within the homogeneous universe 95

II.13 Milieu: the situation explicated through character actions 99

II.14 Binomial: a whole world of duels 100

II.15 Imprint: an indelible impression of the world upon a character 101

II.16 Plastic figure: small form transformed by the large form, an implied situation 106

II.17 Theatrical figure: a sequence of images as precursor of the real $\begin{array}{ll}\text { action } & 107\end{array}$

II.18 Mise en abyme: a recurrence of plastic and theatrical figures 108

II.19 Figure of the sublime: actions surpass the determinates of an enfeebled situation 
II.20 Figure of enfeeblement: weak characters reveal the sublime nature of the world

II.2I Quotidian: everyday situations, everyday actions - sublime $\leftrightarrow$ futile

II.22 Limit of the large form action-image: action explores a hidden problem

II.23 Limit of the small form action-image: the situation revealed as a problem

II.24 Extreme limit of the action-image: a whole world of problems

II.25 Rich dreams: radically distinct real world and dream world

II.26 Restrained dreams: an ambiguity between real world and dream world

II.27 Movement of world: the dream world is the real world

II.28 Strong destiny: a flashback to the past determines the future

II.29 Weak destiny: the content of the flashback permeates affects

II.30 Forking paths: a matrix of irresolvable flashbacks

II.31 Mark: the relation between a habitual series of images

II.32 Demark: an aberration in the series of habitual images

II.33 Symbol: an object expressing ideas, beliefs, concepts

II.34 Opsigns and sonsigns: the zeroness of the time-image

II.35 Mirrors face to face: fragments, duplicates and distortions

II.36 Limpid-opaque: the exchange of the actual and virtual

II.37 Seed-environment: (virtual/actual) seed $\leftrightarrow($ actual/virtual) environment

II.38 Peaks of the present: the heterogeneous present

II.39 Sheets of the past: the non-chronological nature of the past

II.40 Powers of the false: serialism, the ongoing ungrounding of the image

II.41 Body of attitude: a dispersed individuation of the body

II.42 Body of gest: the linkage of attitudes creating differentiation

II.43 Cinema of the brain: the screen as a cerebral space

II.44 Lectosigns: the infinite of the time-image

Section III - Cinematographics (1995-2015)

III.01 The Diving Bell and the Butterfly (Julian Schnabel, 2007) 179

III.02 Timecode (Mike Figgis, 2000)

III.03 Naqoyqatsi (Godfrey Reggio, 2002)

III.04 The Terrorist (Santosh Sivan, 1998)

III.05 Despicable Me (Pierre Coffin and Chris Renaud, 2010) 
III.06 Four Times (Michelangelo Frammartino, 2010) 196

III.07 The Human Centipede (First Sequence) (Tom Six, 2009) 201

III.08 Harry Potter and the Deathly Hallows: Part 2 (David Yates, 2011) 205

III.09 Innocence (Lucile Hadzihalilovic, 2004) 209

III.10 Mother (Bong Joon-ho, 2009) 213

III.11 The Killer Inside Me (Michael Winterbottom, 2010) 217

III.12 Ajami (Scandar Copti and Yaron Shani, 2009) 221

III.13 marxism today (prologue) (Phil Collins, 2010) 224

III.14 Made in Dagenham (Nigel Cole, 2010) 228

III.15 Fish Tank (Andrea Arnold, 2009) 234

III.16 The Wandering Cloud (Tsai Ming-liang, 2005) 238

III.17 Scott Pilgrim vs. the World (Edgar Wright, 2010) 241

III.18 Source Code (Duncan Jones, 2011) 244

III.19 Four Lions (Christopher Morris, 2010) 248

III.20 Slackistan (Hammad Khan, 2009) 251

III.21 A Screaming Man (Mahamat-Saleh Haroun, 2010) 255

III.22 Monsters (Gareth Edwards, 2010) 258

III.23 Brooklyn's Finest (Antoine Fuqua, 2009) 261

III.24 Metro Manila (Sean Ellis, 2013) 264

III.25 Star Trek - First Contact (Jonathan Frakes, 1996) 268

III.26 The Machinist (Brad Anderson, 2004) 270

III.27 Inception (Christopher Nolan, 2010) 272

III.28 The Secret in Their Eyes (Juan José Campanella, 2009) 275

III.29 White Material (Claire Denis, 2009) 279

III.30 Triangle (Christopher Smith, 2009) 282

III.31 Se7en (David Fincher, 1995) 286

III.32 Doctor Who - The Day of the Doctor (Nick Hurran, 2013) 289

III.33 Buried (Rodrigo Cortés, 2010) 294

III.34 Five (Abbas Kiarostami, 2003) 299

III.35 Black Swan (Darren Aronofsky, 2010) 305

III.36 Self Made (Gillian Wearing, 2010) 309

III.37 Synecdoche, New York (Charlie Kaufman, 2008) 314

III.38 Uncle Boonmee Who Can Recall His Past Lives
(Apichatpong Weerasethakul, 2010)

III.39 Russian Ark (Alexander Sukurov, 2002) 320

III.40 24 City (Zhang Ke Jia, 2008) 325

III.41 I'm Not There (Todd Haynes, 2007) 328

III.42 Police, Adjective (Corneliu Porumboiu, 2009) 330

III.43 Dogville (Lars von Trier, 2003) 335

III.44 Enter the Void (Gaspar Noé, 2009) 337 
